\title{
Prevention of SURGical site Infections in ORTHOpaedics
}

\author{
Róża Słowik' $1 \mathrm{AB,BD}$, Marta Zofia Wałaszek ${ }^{2 E, F}$, Małgorzata Kołpa ${ }^{2 C, E}$
}

'Orthopaedics Department, Provincial Hospital, Tarnow, Poland

2Department of Nursing, State Higher Vocational School, Tarnow, Poland

Authors' contribution:

A. Study design/planning $\bullet$ B. Data collection/entry $\bullet$ C. Data analysis/statistics $\bullet$ D. Data interpretation $\bullet$ E. Preparation of manuscript $\bullet$ F. Literature analysis/search $\bullet$ G. Funds collection

\author{
Address for correspondence: \\ Dr hab. Marta Zofia Wałaszek \\ Department of Nursing \\ State Higher Vocational School \\ Tarnow, Poland \\ e-mail: mz.walaszek@gmail.com \\ SUBMITTED: 18.11 .2021 \\ ACCEPTED: 06.12.2021 \\ DOl: https://doi.org/10.5114/ppiel.2021.113787
}

\begin{abstract}
Surgical site infections (SSI) are some of the most serious postoperative complications. Orthopaedic surgery involves a higher risk of developing SSI due to inserting implants into bones that have a very sensitive structure and a good blood supply. The ability to identify and classify SSI contributes to prompt treatment and better prognosis. Prevention of SSI encompassing preoperative, intraoperative, and postoperative periods should result in the optimal health condition of the patient prior to surgery, and professional preparation of the treatment team and the environment during the operation and postoperative care.

This study is a review of global guidelines concerning the prevention of surgical site infections, with particular emphasis on orthopaedics and traumatology.

Key words: surgical site infections, surgical site infection prevention, orthopaedics, perioperative care.
\end{abstract}

\section{INTRODUCTION}

Advances in medicine resulting from the improvement of surgical techniques and the introduction of more and more modern instruments have significantly improved the quality of life of patients treated for diseases of the musculoskeletal system. This progress, however, does not eliminate the risk of developing surgical site infections (SSI) [1].

Surgical site infections are healthcare-associated infections (HAl), and they are still some of the most severe complications emerging in contemporary surgery, which can be prevented or reduced to a minimum. Surgeries conducted on the bone tissue, which is sensitive to infection, require the operator to scrupulously follow the rules of the sanitary regime. The occurrence of a complication in the form of SSI changes the lives of patients completely, prolongs their hospital stay, lowers their quality of life, prolongs their inability to work, and can lead to disability and even death. The prestige of the institution also experiences a decline as a result of court claims. The negative effects of SSI also bring about increased costs due to prolonged hospitalization, performing additional diagnostic tests and operations, or administering antibiotic therapy [1-4].

In European studies, SSIs accounted for approximately $27 \%$ of all hospital-acquired infections [5]. In Poland, in one study, SSIs were in second position in the structure of hospital-acquired infections and accounted for $23 \%$ of all HAls [6]. In another analy- sis from 2001-2004, SSIs amounted to $32 \%$ and took the first place among all HAls detected in the facility under study [7]. Such a high percentage of SSIs in the general pool of hospital-acquired infections also results in increased costs of patient treatment $[8,9]$. In the literature, a wide incidence rate of SSIs can be found in orthopaedic surgery, which ranges from $1 \%$ to $14 \%$ depending on the type of surgery and coexisting risk factors [10-17].

One of the most vital actions as regards the surveillance of SSIs is detecting the SSI itself and documenting it through the knowledge of the HAl criteria and definitions. Activities undertaken in order to prevent SSIs should include clear and consistent procedures, which will prepare the patient for surgery in the optimal way and reduce the risk of SSI at every stage of hospital care.

This study is a review of global guidelines concerning the prevention of surgical site infections, with particular emphasis on orthopaedics and traumatology. It is not a systematic review; the selection of literature was conducted with the use of PubMed and Google Scholar databases. The analysed literature concerned surgical site infections and recommendations for SSI prophylaxis, particularly pertaining to orthopaedic and traumatology procedures. While looking for the material, the following key words were used: surgical site infections (SSI), SSI risk factors, orthopaedics, fractures, SSI prevention, antibiotic prophylaxis. 


\section{CRITERIA FOR DIAGNOSING SURGICAL SITE INFECTIONS}

Surgical site infections are diagnosed and categorized according to the definitions and criteria accepted by the European Centre for Disease Prevention and Control (ECDC), which constitute the guidelines for the countries forming the European Union (EU) $[18,19]$

Surgical site infections can be categorized into superficial, deep, and organ/space infections. In order to classify SSI into a particular group, the following criteria need to be met:

- superficial incisional SSI (SSI-S) is an infection that develops within 30 days of surgery, affects only the skin and subcutaneous tissue at the site of the incision, and meets at least one of the following conditions:

- the presence of laboratory-confirmed or unconfirmed purulent discharge from the site of the superficial incision,

- a positive fluid or tissue culture from the superficial incision site, performed under aseptic conditions,

- at least one of the local symptoms of inflammation: pain, swelling, tension, tenderness, redness, or local warmth,

- deliberate opening of the surgical wound by the surgeon, except when there are no microorganisms in the incision,

- diagnosis of SSI-S from a doctor;

- deep SSI (SSI-D) can be diagnosed when an infection appears within 30 days of an operation that did not involve implantation of artificial elements, and if an implant is implanted, it is up to 90 days following the operation. If the implant is kept, and the infection is associated with the surgery and affects deeply located soft tissues (muscles and fascia), at the incision site, and meets one of the following conditions:

- the presence of purulent discharge from deep layers around the incision (but not from the organs or body cavities),

- spontaneous wound dehiscence or its deliberate opening by the surgeon, if at least one of the following symptoms occurs: fever $\left(>38^{\circ} \mathrm{C}\right)$, local pain, or tenderness, unless a negative culture is obtained,

- the presence of an abscess or other symptoms of infection demonstrated during a physical examination, re-surgery, whether confirmed by the results of histopathological or radiological examinations,

- diagnosis of SSI-D from a doctor;

- organ/space SSI (SSI-O) appears within 30 days of the operation if an artificial implant was not implanted or within 90 days if a biomaterial was implanted during the operation and the infection may be associated with the surgery performed and includes any anatomical site other than the area of the incision of the integuments and the site that was opened or compromised during the operation, where at least one of the following circumstances is true:

- purulent discharge from the drain inserted through a puncture wound into an organ or body cavity,

- isolation of a microorganism from the culture of fluid or tissues from body cavities or an organ carried out under aseptic conditions,

- the presence of an abscess or other clinical signs of an organ/cavity infection, found in the course of a physical examination, re-surgery, or in histopathological or imaging examinations,

- diagnosis of SSI-O from a doctor.

\section{HAND HYGIENE}

One of the most important, and at the same time the simplest, SSI prevention procedures is hand hygiene. In 2009, the World Health Organization (WHO) [20] issued recommendations that include all the components of hygiene: preparation of hands, indications for washing and disinfection, proper decontamination techniques, proper selection of preparations for hand washing and disinfection, proper use of protective gloves as well as education and supervision of compliance with hand hygiene. It is recommended that hands are disinfected with an alcohol-based agent, which is held in higher regard than washing hands with soap and water, except for when there is visible contamination of hands that have been exposed to biological material, or after contact with a patient suspected of or diagnosed with the presence of sporeforming microorganisms, e.g. Clostridium difficile. The next significant element of hand hygiene is the bare below the elbow principle, which aims at preventing the transmission of microorganisms found on white coats, under jewellery, or on watches and bracelets. It is also recommended to have natural nails with length of up to $0.5 \mathrm{~cm}$. The hand hygiene procedures recommended by the WHO involve 5 indications (moments) related to the provision of health services, and these are: before and after touching a patient, before clean procedure, after body fluid exposure (dirty procedure), and after touching patient surroundings. For proper hand decontamination, Ayliffe's 6-step technique should be employed, in which the sequence of steps and the number of repetitions are of importance. The use of protective gloves is an important aspect. The WHO recommends their use in the situations when one expects to come into contact with blood or another biological material, damaged skin, or mucous membrane. Hands should be disinfected before put- 
ting on the gloves and after taking them off. Gloves should be changed or removed when moving from one dirty procedure to another [20].

\section{PREVENTION OF SURGICAL SITE INFECTIONS IN ORTHOPAEDIC SURGERIES}

For many years, attempts have been made to develop a single standard of care as regards the prevention of SSI. In the literature, there are many recommendations concerning this topic, and these have developed over the years, depending on the country, the facility, or the surgical procedure carried out. Even though there are still no clear international standards or recommendations and there is an ongoing discussion on this subject, the literature indicates comparable recommendations from WHO, Centres for Disease Control and Prevention (CDC), or the National Institute for Health and Care Excellence (NICE) and from other institutions, and these recommendations are constantly being updated.
Table 1 lists the recommendations of individual organizations regarding the prevention of SSI in orthopaedic surgery [21-33].

\section{PERIOPERATIVE ANTIBIOTIC PROPHYLAXIS IN ORTHOPAEDIC SURGERY}

Perioperative antibiotic prophylaxis (PAP) is one of the more significant elements of SSI prevention, which is generally applied in clean procedures with the insertion of an implant or in clean-contaminated procedures, which should not be confused with dirty procedures, in which antibiotic therapy is used. PAP consists of short-term administration of an antibiotic to the operated patient before the skin incision to reduce intraoperative microbial contamination to a level at which the body can fight the infection. The choice of antibiotic is dependent on the type of procedure and risk factors; the time of antibiotic administration depends on its half-life; and the duration of using it in PAP depends on the procedure type.

Table 1. Overview of recommendations concerning the prevention of surgical site infections in orthopaedic surgery

\begin{tabular}{|c|c|}
\hline \multirow[t]{7}{*}{ Bath before surgery } & Recommended, ordinary soap or an antibacterial agent can be used. WHO [21] \\
\hline & Recommended, using soap or an antibacterial agent the evening before surgery. CDC [23] \\
\hline & $\begin{array}{l}\text { Recommended the day before surgery or on the day of surgery. Ireland \& Royal College } \\
\text { of Surgeons in Ireland [25] }\end{array}$ \\
\hline & $\begin{array}{l}\text { Body bath with chlorhexidine is recommended (which reduces the concentration of pathogens } \\
\text { on the skin, but it does not reduce the frequency of SSI). Infection Society [24] }\end{array}$ \\
\hline & $\begin{array}{l}\text { Recommended, the day before surgery or on the day of surgery using ordinary soap. Health } \\
\text { Protection Scotland [26] }\end{array}$ \\
\hline & $\begin{array}{l}\text { It is recommended to have a bath with chlorhexidine gluconate at least } 3 \text { days before the } \\
\text { procedure. Institute for Healthcare Improvement: hip and knee arthroplasty [27] }\end{array}$ \\
\hline & $\begin{array}{l}\text { Recommended, at least } 1 \text { time before the procedure with soap or antibacterial soap. Asia Pacific } \\
\text { Society of Infection Control (APSIC) [28] }\end{array}$ \\
\hline \multirow{5}{*}{$\begin{array}{l}\text { Prevention of Staphylococcus } \\
\text { aureus infections through } \\
\text { screening and nasal } \\
\text { decolonization using } \\
2 \% \text { mupirocin ointment } \\
\text { and/or a body bath with } \\
\text { the use of chlorhexidine } \\
\text { gluconate }\end{array}$} & Recommended for orthopaedic patients who carry S. aureus. WHO [21] \\
\hline & $\begin{array}{l}\text { It is recommended to perform nasal decolonization with mupirocin ointment and body bath with } \\
\text { chlorhexidine in patients undergoing surgery, where S. aureus is a risk factor for SSI. NICE [22] }\end{array}$ \\
\hline & $\begin{array}{l}\text { Screening tests are recommended for patients undergoing orthopaedic surgery; in carriers } \\
\text { of S. aureus (MRSA), implementation of the decolonization protocol. SHEA/IDSA [30] }\end{array}$ \\
\hline & $\begin{array}{l}\text { Screening tests are recommended for arthroplasty patients; in carriers of S. aureus (MRSA), } \\
\text { implementation of the decolonization protocol. American College of Surgeons and Surgical } \\
\text { Infection Society [24] }\end{array}$ \\
\hline & $\begin{array}{l}\text { Screening tests are recommended; in carriers of S. aureus, implementation of the decolonization } \\
\text { protocol. Health Protection Scotland [26] }\end{array}$ \\
\hline
\end{tabular}


Table 1. Overview of recommendations concerning the prevention of surgical site infections in orthopaedic surgery (cont.)

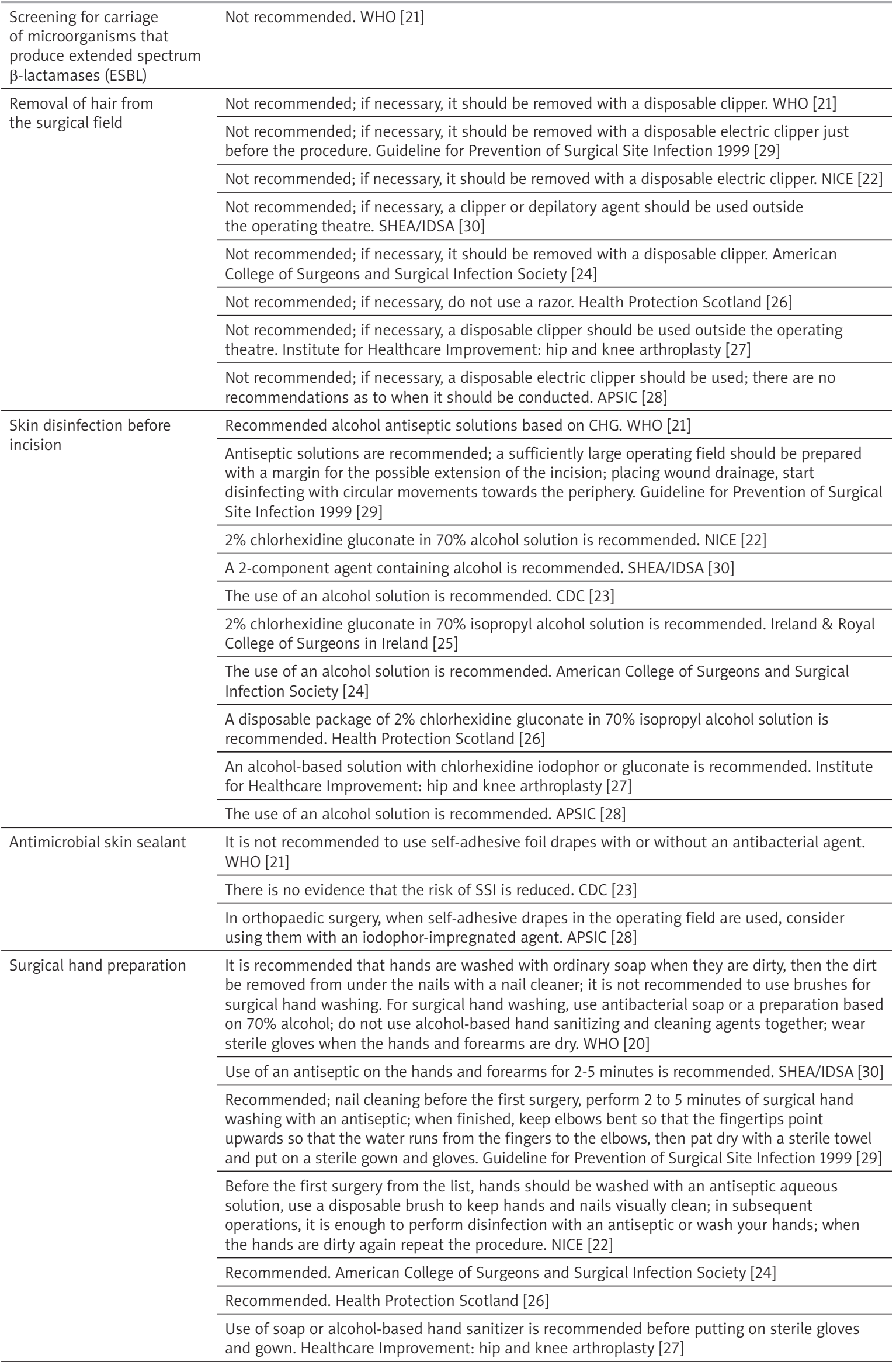


Table 1. Overview of recommendations concerning the prevention of surgical site infections in orthopaedic surgery (cont.)

\begin{tabular}{|c|c|}
\hline \multirow[t]{2}{*}{$\begin{array}{l}\text { Increasing nutritional } \\
\text { support }\end{array}$} & $\begin{array}{l}\text { Recommended; administration of nutrient-enriched oral or enteral formulations in underweight } \\
\text { patients or in patients undergoing major surgery. WHO [21] }\end{array}$ \\
\hline & $\begin{array}{l}\text { Recommended in malnourished patients, especially before major surgery, and in oncological } \\
\text { patients. Healthcare Improvement: hip and knee arthroplasty [27] }\end{array}$ \\
\hline \multirow{4}{*}{$\begin{array}{l}\text { Discontinuation } \\
\text { of immunosuppressive } \\
\text { treatment in the } \\
\text { perioperative period }\end{array}$} & Not recommended. WHO [21] \\
\hline & Recommended. SHEA/IDSA [30] \\
\hline & No recommendations. Guideline for Prevention of Surgical Site Infection 1999 [29] \\
\hline & No recommendations. CDC [23] \\
\hline \multirow[t]{7}{*}{ Perioperative oxygen therapy } & $\begin{array}{l}\text { In adults under general anaesthesia with endotracheal intubation, it is recommended that } \\
\text { a breathing mixture containing } 80 \% \text { oxygen be administered, also during and after } \\
\text { the procedure for a period of 2-6 hours. WHO [21] }\end{array}$ \\
\hline & $\begin{array}{l}\text { It is recommended that the haemoglobin oxygen saturation be kept at } 95 \% \text { during surgery and } \\
\text { during the recovery period. NICE [22] }\end{array}$ \\
\hline & $\begin{array}{l}\text { It is recommended that optimal tissue oxygenation be maintained in the perioperative period. } \\
\text { SHEA/IDSA [30] }\end{array}$ \\
\hline & $\begin{array}{l}\text { In patients with normal lung function under general endotracheal anaesthesia, it is } \\
\text { recommended that increased } \mathrm{F}_{1} \mathrm{O}_{2} \text { be administered during and after the } \mathrm{CDC} \text { procedure [23] }\end{array}$ \\
\hline & $\begin{array}{l}\text { It is recommended that the haemoglobin oxygen saturation be kept above } 95 \% \text {. Ireland \& Royal } \\
\text { College of Surgeons in Ireland [25] }\end{array}$ \\
\hline & $\begin{array}{l}\text { Under general anaesthesia, it is recommended that a breathing mixture containing } 80 \% \text { oxygen } \\
\text { be administered. American College of Surgeons and Surgical Infection Society [24] }\end{array}$ \\
\hline & $\begin{array}{l}\text { It is recommended that the haemoglobin oxygen saturation be kept above } 95 \% \text {. Health } \\
\text { Protection Scotland [26] }\end{array}$ \\
\hline \multirow[t]{8}{*}{ Maintaining normothermia } & $\begin{array}{l}\text { It is recommended that body heating devices are used in the operating room and during } \\
\text { the procedure. WHO [21] }\end{array}$ \\
\hline & Recommended. NICE [22] \\
\hline & $\begin{array}{l}\text { It is recommended that the body temperature is maintained at } 35.5^{\circ} \mathrm{C} \text { or higher in the peri- } \\
\text { operative period. SHEA/IDSA [30] }\end{array}$ \\
\hline & Recommended. CDC [23] \\
\hline & $\begin{array}{l}\text { It is recommended that the body temperature is maintained above } 36^{\circ} \mathrm{C} \text { in the perioperative } \\
\text { period. Ireland \& Royal College of Surgeons in Ireland [25] }\end{array}$ \\
\hline & Recommended. American College of Surgeons and Surgical Infection Society [24] \\
\hline & It is recommended that the body temperature is kept above $36^{\circ} \mathrm{C}$. Health Protection Scotland [26] \\
\hline & Recommended. APSIC [28] \\
\hline \multirow{9}{*}{$\begin{array}{l}\text { Maintaining intensive } \\
\text { glycaemic control protocol } \\
\text { in the perioperative period }\end{array}$} & $\begin{array}{l}\text { Recommended for both diabetic and non-diabetic patients; there are no recommendations as to } \\
\text { the optimal glycaemic standards in the perioperative period. WHO [21] }\end{array}$ \\
\hline & $\begin{array}{l}\text { Recommended in patients with diabetes mellitus; avoiding hyperglycaemia is recommended. } \\
\text { Guideline for Prevention of Surgical Site Infection } 1999 \text { [29] }\end{array}$ \\
\hline & $\begin{array}{l}\text { Routine administration of insulin to maintain normoglycaemia is not recommended } \\
\text { in nondiabetic patients. NICE [22] }\end{array}$ \\
\hline & It is recommended that postoperative glycaemia be maintained at < $180 \mathrm{mg} / \mathrm{dl}$. SHEA/IDSA [30] \\
\hline & $\begin{array}{l}\text { It is recommended that perioperative glycaemia be maintained in patients with and without } \\
\text { diabetes at the level of }<200 \mathrm{mmol} / \mathrm{dl} \text {. CDC [23] }\end{array}$ \\
\hline & $\begin{array}{l}\text { In diabetic patients, glucose maintenance is recommended at }<11 \mathrm{mmol} / \mathrm{l} \text {. Ireland \& Royal } \\
\text { College of Surgeons in Ireland [25] }\end{array}$ \\
\hline & $\begin{array}{l}\text { It is recommended that glycaemia be maintained in the perioperative period at the level } \\
\text { of } 110-150 \mathrm{mg} / \mathrm{dl} \text {. American College of Surgeons and Surgical Infection Society [24] }\end{array}$ \\
\hline & $\begin{array}{l}\text { It is recommended that glycaemia be maintained in a patient with diabetes at the level } \\
\text { of }<11 \mathrm{mmol} / \mathrm{l} \text { during the operative period. Health Protection Scotland [26] }\end{array}$ \\
\hline & $\begin{array}{l}\text { Recommended; in order to keep the preoperative level of } \mathrm{HbA}_{1 \mathrm{c}} \text { below } 8 \% \text {, it is recommended } \\
\text { that perioperative glycaemia be maintained in diabetic and non-diabetic patients } \\
\text { at } 140-200 \mathrm{mg} / \mathrm{dl} \text {. Institute for Healthcare Improvement: hip and knee arthroplasty [27] }\end{array}$ \\
\hline
\end{tabular}


Table 1. Overview of recommendations concerning the prevention of surgical site infections in orthopaedic surgery (cont.)

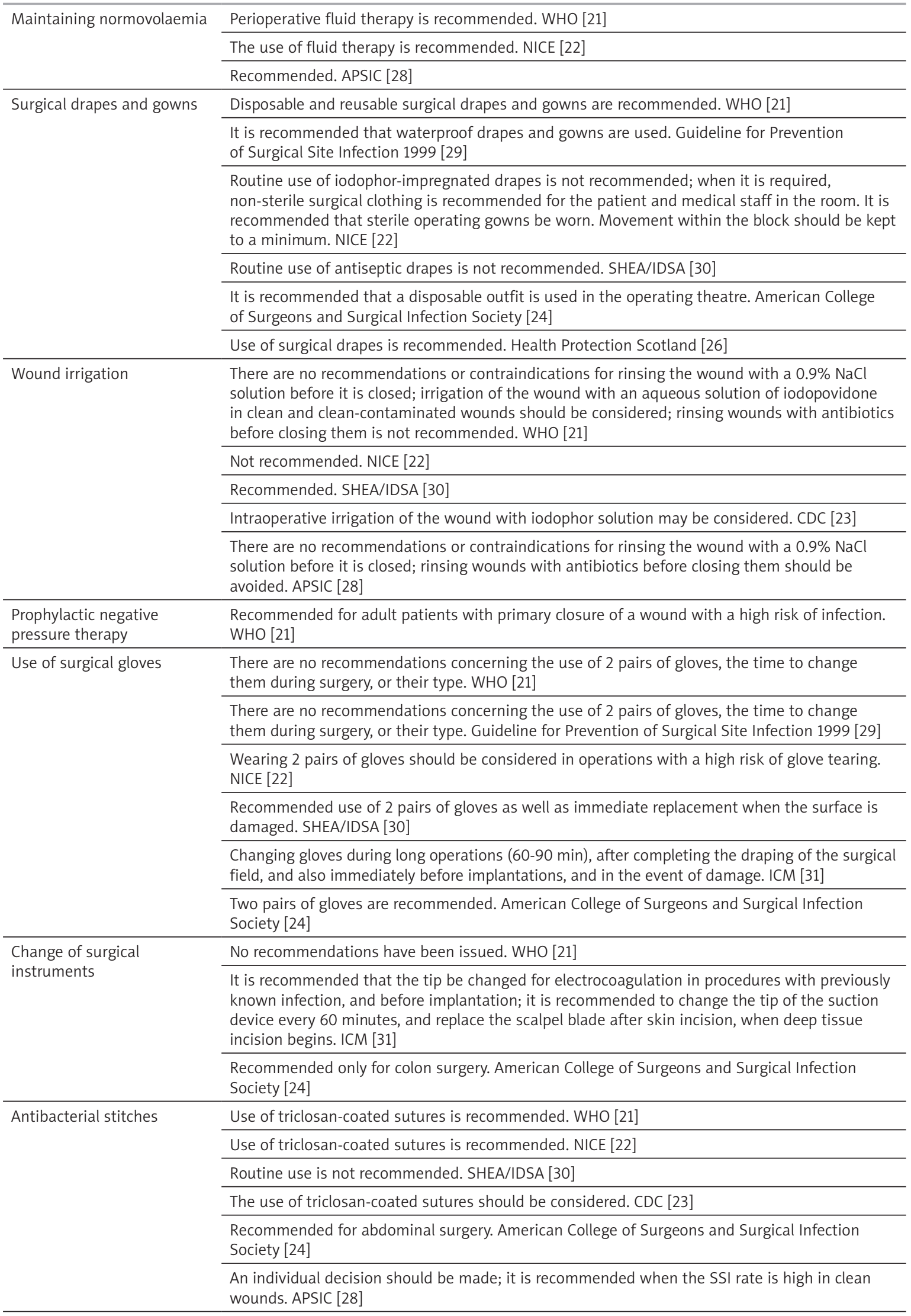


Table 1. Overview of recommendations concerning the prevention of surgical site infections in orthopaedic surgery (cont.)

\begin{tabular}{|c|c|}
\hline \multirow[t]{6}{*}{ Laminar flow theatre } & It is not recommended during total arthroplasty. WHO [21] \\
\hline & $\begin{array}{l}\text { The use of laminar airflow in arthroplasty should be considered. Guideline for Prevention } \\
\text { of Surgical Site Infection } 1999 \text { [29] }\end{array}$ \\
\hline & $\begin{array}{l}\text { Not recommended for arthroplasty. CDC and Healthcare Infection Control Practices Advisory } \\
\text { Committee (HICPAC) [32] }\end{array}$ \\
\hline & $\begin{array}{l}\text { Recommended in primary and revision arthroplasty, with the use of bone implants and internal } \\
\text { anastomoses. Royal College of Anaesthetists [33] }\end{array}$ \\
\hline & Not recommended for clean orthopaedic surgeries and elective arthroplasty. ICM [31] \\
\hline & Not recommended. APSIC [28] \\
\hline \multirow[t]{4}{*}{ Specialized dressings } & It is not recommended, comparable with a standard dressing. WHO [21] \\
\hline & Use of a specialized dressing is recommended after surgical wound closure. NICE [22] \\
\hline & $\begin{array}{l}\text { A sterile dressing is recommended after the wound is closed. Ireland \& Royal College of Surgeons } \\
\text { in Ireland [25] }\end{array}$ \\
\hline & Not recommended for routine use. APSIC [28] \\
\hline \multirow[t]{5}{*}{ Changing the dressing } & $\begin{array}{l}\text { It is recommended that a sterile dressing be kept for a period of } 24 \text { to } 48 \text { hours in the case } \\
\text { of wounds with the primary suture; apply the principles of asepsis; use the sterile technique } \\
\text { when a dressing change is required; no recommendations were made to maintain the dressing } \\
\text { after } 48 \text { h, or when to take a post-operative body shower. Guideline for Prevention of Surgical } \\
\text { Site Infection } 1999 \text { [29] }\end{array}$ \\
\hline & $\begin{array}{l}\text { Employ the contactless technique to change the dressing; change the dressing using saline } \\
\text { in the first } 48 \text { hours; change the dressing using tap water after } 48 \text { hours; the patient can take } \\
\text { a shower } 48 \text { hours after the surgery. NICE [22] }\end{array}$ \\
\hline & $\begin{array}{l}\text { Do not change the dressing or tamper with it for up to } 48 \text { hours after the procedure, unless } \\
\text { it is advisable; use the contactless technique to change the dressing. Ireland \& Royal College } \\
\text { of Surgeons in Ireland [25] }\end{array}$ \\
\hline & $\begin{array}{l}\text { There are no recommendations as to when to change the dressing or how long to keep the } \\
\text { dressing on; you can shower } 12 \text { hours after the surgery - no evidence of an increased risk of SSI. } \\
\text { American College of Surgeons and Surgical Infection Society [24] }\end{array}$ \\
\hline & $\begin{array}{l}\text { It is recommended that a sterile dressing be put on at the end of the procedure and kept } \\
\text { for } 48 \text { hours after the surgery; changing the dressing is possible earlier when there is excessive } \\
\text { leakage from the wound, using the non-contact technique of changing the dressing; Health } \\
\text { Protection Scotland [26] }\end{array}$ \\
\hline & $\begin{array}{l}\text { Control, CDC - Centres for Disease Control and Prevention, CHG - chlorhexidine gluconate, ESBL - } \beta \text {-lactamases } \\
\text { 1c - glycated haemoglobin, HICPAC - Healthcare Infection Control Practices Advisory Committee, ICM - The } \\
\text { iprosthetic Joint Infection, MRSA - methicillin-resistant Staphylococcus aureus, NICE - National Institute for Health } \\
\text { jociety for Healthcare Epidemiology of America/IIfectious Diseases Society of America, WHO - World Health }\end{array}$ \\
\hline
\end{tabular}

In Table 2, recommendations concerning PAP in orthopaedic surgery from selected institutions are summarized. The individual recommendations do not vary as regards the recommendations to administer an additional intraoperative dose if the procedure time is extended or there is a significant blood loss, or if the procedure involves the implantation of joint prostheses [21, 22, 24, 25, 30, 34-39].

The literature review that was carried out points to the fact that due to the growing number of orthopaedic procedures requiring insertion of implants, an increased percentage of SSIs can be expected. These infections have a significant impact on the patients' health. Although they cannot be completely eliminated, the use of SSI prophylaxis can substantially reduce the infection rate. Knowledge regarding the methods for SSI prevention should be popularized, and medical staff should be made aware of the consequences of developing infections. The recom- mendations mentioned in this study may become a vital factor in reducing the number of infections and their complications. An attempt was made to collect recommendations concerning the prevention of SSI from several medical institutions. It is necessary to put greater focus on SSI because perioperative antibiotic prophylaxis, asepsis, and antiseptics do not solve the problem of infections. The recommendations presented in this study will allow to the patient to be reliably prepared for surgery and the course of the procedure to be optimized, improving patient safety and the quality of postoperative care, and reducing the percentage of SSIs in orthopaedic surgeries.

In the presented work, the recommendations of individual organizations may differ from each other due to the method of identifying priority topics, asked questions, perception of critical points, research methodology, and the method of obtaining evidence. 
Table 2. Recommendations of selected medical institutions regarding antibiotic prophylaxis in orthopaedic procedures

\begin{tabular}{|c|c|c|c|c|}
\hline $\begin{array}{l}\text { Name of the } \\
\text { institution }\end{array}$ & $\begin{array}{l}\text { Time of } \\
\text { administration } \\
\text { before skin } \\
\text { incision }\end{array}$ & $\begin{array}{l}\text { A single preoperative } \\
\text { dose of antibiotics } \\
\text { without } \\
\text { re-administration } \\
\text { during and after } \\
\text { surgery }\end{array}$ & $\begin{array}{c}\text { Additional intraoperative } \\
\text { doses }\end{array}$ & Perioperative prophylaxis \\
\hline $\begin{array}{l}\text { The Scottish } \\
\text { Antimicrobial } \\
\text { Prescribing Group } \\
\text { (SAPG) [36] }\end{array}$ & $60 \mathrm{~min}$ & $\begin{array}{l}\text { A single dose is } \\
\text { recommended }\end{array}$ & $\begin{array}{l}\text { It is recommended } \\
\text { that another dose be } \\
\text { administered if the operation } \\
\text { lasts longer than } 4 \text { hours } \\
\text { or if blood loss during the } \\
\text { operation exceeds } 1500 \mathrm{ml}\end{array}$ & $\begin{array}{l}\text { It is recommended when } \\
\text { it is an open fracture; } \\
\text { administration as soon as } \\
\text { possible - max. up to } 3 \text { hours } \\
\text { since injury; administer for } \\
72 \text { hours or until the surgical } \\
\text { wound closes; a single } \\
\text { dose in closed fractures; } \\
\text { in primary or revision } \\
\text { arthroplasty: prophylaxis up } \\
\text { to } 24 \text { hours }\end{array}$ \\
\hline
\end{tabular}

\begin{tabular}{lc}
\hline $\begin{array}{l}\text { American Society } \\
\text { of Health-System }\end{array}$ & $\begin{array}{c}\text { It is recommended } \\
\text { that another dose be }\end{array}$ \\
Pharmacists (ASHP) & 60 min \\
[37] & administered if the operation \\
lasts longer than 4 hours or if \\
there is significant blood loss
\end{tabular}

It is recommended in primary or revision arthroplasty, insertion of other implants,

or in trauma surgeries: there is significant blood loss prophylaxis up to 24 hours

\begin{tabular}{|c|c|c|}
\hline $\begin{array}{l}\text { American College } \\
\text { of Surgeons }\end{array}$ & $60 \mathrm{~min}$ & $\begin{array}{l}\text { Recommended for } \\
\text { clean procedures }\end{array}$ \\
\hline
\end{tabular}

It is recommended

that another dose be

and Surgical Infection

that another dose be
administered if the operation

Society [24]

is prolonged or if blood loss

during the operation exceeds

Recommended in

arthroplasty, without

recommendation on the

duration of use

$1500 \mathrm{ml}$

\begin{tabular}{lcc}
\hline $\begin{array}{l}\text { Department for } \\
\text { Health and Ageing, }\end{array}$ & It is recommended & Up to 24 hours, not \\
Government of South & that another dose be & recommended for clean \\
Australia [38] & administered if the operation & procedures without \\
is prolonged to up to 4 hours & implantation
\end{tabular}

of blood during surgery

\begin{tabular}{|c|c|c|c|}
\hline $\begin{array}{l}\text { National Institute } \\
\text { for Health and Care } \\
\text { Excellence (NICE) [22] }\end{array}$ & $\begin{array}{l}\text { Clean procedures, } \\
\text { without implants or } \\
\text { joint prostheses }\end{array}$ & $\begin{array}{l}\text { It is recommended } \\
\text { that another dose be } \\
\text { administered if the operation } \\
\text { is longer than the half-life } \\
\text { of the antibiotic given }\end{array}$ & $\begin{array}{l}\text { Recommended } \\
\text { in arthroplasty and with } \\
\text { implants, in procedures } \\
\text { with clean-contaminated } \\
\text { and dirty wounds without } \\
\text { recommendation on duration }\end{array}$ \\
\hline
\end{tabular}

\begin{tabular}{|c|c|c|c|}
\hline WHO [21] & $120 \mathrm{~min}$ & & $\begin{array}{l}\text { Recommended for } \\
\text { arthroplasty }\end{array}$ \\
\hline SHEA/IDSA [30] & $60 \min$ & $\begin{array}{l}\text { It is recommended } \\
\text { that another dose be } \\
\text { administered if the operation } \\
\text { exceeds } 2 \text { half-lives of the } \\
\text { antibiotic given or there is } \\
\text { a lot of blood loss during the } \\
\text { procedure }\end{array}$ & Up to 24 hours \\
\hline
\end{tabular}

\begin{tabular}{|c|c|c|c|c|}
\hline $\begin{array}{l}\text { Royal College } \\
\text { of Physicians } \\
\text { of Ireland [25] }\end{array}$ & $60 \mathrm{~min}$ & $\begin{array}{l}\text { A single dose is } \\
\text { recommended }\end{array}$ & $\begin{array}{l}\text { It is recommended } \\
\text { that another dose be } \\
\text { administered if the operation } \\
\text { lasts longer than } 4 \text { hours } \\
\text { or when blood loss during } \\
\text { surgery exceeds } 1500 \mathrm{ml}\end{array}$ & $\begin{array}{l}\text { Prophylaxis up to } 24 \text { hours } \\
\text { only for arthroplasty }\end{array}$ \\
\hline $\begin{array}{l}\text { National Program } \\
\text { for the Protection } \\
\text { of Antibiotics [34, 35] }\end{array}$ & $30 \mathrm{~min}$ & $\begin{array}{l}\text { Clean-contaminated } \\
\text { procedures, closed } \\
\text { long bone fractures }\end{array}$ & $\begin{array}{c}\text { It is recommended } \\
\text { that another dose be } \\
\text { administered if the operation } \\
\text { is longer than the half-life } \\
\text { of the antibiotic given }\end{array}$ & $\begin{array}{c}\text { Prophylaxis is recommended } \\
\text { when it is an open fracture } \\
\text { according to the Gustilo } \\
\text { and Anderson classification, } \\
\text { grade I and II up to } \\
24 \text { hours, and grade III up to } \\
72 \text { hours, up to } 24 \text { hours in } \\
\text { arthroplasty }\end{array}$ \\
\hline
\end{tabular}

ASHP-American Society of Health-System Pharmacists, NICE - National Institute for Health and Care Excellence, SAPG - The Scottish Antimicrobial Prescribing Group, SHEA/IDSA - The Society for Healthcare Epidemiology of America/Infectious Diseases 
Global SSI oversight aims to standardize recommendations with proven effectiveness. The issued recommendations should be universal, innovative, and applicable in countries supervising SSI [21]. The application of these recommendations is not obligatory; however, it is expected that they are implemented according to the patient's needs and the possibility of their implementation in a given country [22, 40]. In line with the recommendations of the WHO and the European Commission, each country should have a developed HAl control strategy, including a strategy for SSI supervision at the national level. In Poland, however, there is no opinion-forming centre operating in the area of HAl prophylaxis [41]. One of the tasks of such a centre could be SSI prophylaxis, e.g. in the field of HPRO and KPRO, and others, such as staff hand hygiene and drug resistance monitoring [19, 41]. Centres of this type, which exist in other European countries, are expected to issue opinions on recommendations using the GRADE methodology (Grading of Recommendations Assessment, Development, and Evaluation), which can be implemented by consensus with individual organizations and associations. One of the most important documents on which the HAl supervision system in Poland is based are the recommendations of the Council of the European Union of 2009 , which only set out general principles of the system's operation [42]. In Poland, as in other European Union (EU) countries, there is a differentiated approach to SSI monitoring, prevention programs, and personnel competences. ECDC is also attempting to standardize SSI control methods for certain orthopaedic procedures such as KRRO and HPRO in European countries [41]. As a result of the activities of ECDC, the HAI-Net (Healthcare-Associated Infections Surveillance Network), EARS-Net (European Antimicrobial Resistance Surveillance Network), and ESAC-Net (European Surveillance of Antimicrobial Consumption Network) networks were created for the EU countries $[19,41]$.

In Poland, since 1989, attempts have been made to organize the supervision of HAl, but it was not until 2001 that the first legal acts introduced the definition of $\mathrm{HAl}$ and systematized the practice of control. Despite the passage of many years, the passive system of HAl supervision is still dominant in Polish hospitals, the consequence of which is the lack of data necessary for the analysis and conclusions in the field of SSI prophylaxis [41, 43,44]. The Infection Control Teams operating in Polish hospitals have a statutory obligation to develop and update HAI prophylaxis procedures in accordance with the current knowledge, but they rarely receive systemic support in the form of knowledge based on evidence-based medicine (EBM). It seems that the establishment in Poland of a consultative and advisory organizational unit with legal personality, supervised by the minister compe- tent for health, could facilitate the activities of the healthcare management. This organization should evaluate scientific publications and the latest medical technologies in a repeatable, transparent manner, according to a defined methodological standard and based on scientific evidence in accordance with the EBM. However, until such an opinion-forming organization is established, efforts should be made to publish illustrative works by scientists attempting to conduct literature reviews such as this work.

\section{Disclosure}

The authors declare no conflict of interest.

\section{References}

1. Wierdak M, Wójkowska-Mach J, Szczypta A. Pacjent operowany. In: Bulanda M, Wójkowska-Mach J (Eds.). Zakażenia szpitalne w jednostkach opieki zdrowotnej. Wydawnictwo Lekarskie PZWL, Warszawa 2016; 239-255.

2. Fleischer M, Rusiecka-Ziołkowska J, Jermakow K, et al. Dekontaminacja środowiska szpitalnego i jej znaczenie w profilaktyce zakażeń związanych z hospitalizacją. Forum Zakażeń 2015; 6: 217-225.

3. Szewczyk M, Cwajda-Białasik J, Mościcka P, et al. Zalecenia profilaktyki zakażeń miejsca operowanego i stosowania antybiotykoterapii w okresie przedoperacyjnej opieki pielęgniarskiej na oddziałach zabiegowych. Pielęgniarstwo Chirurgiczne i Angiologiczne 2015; 2: 39-55.

4. Nowacki J, Dobrzański L, Gustavo F. Implanty śródszpikowe w osteosyntezie kości długich. Open Access Library 2012.

5. Corporativo ESTUDIO EPINE-EPPS 2017. ECDC, 2016-2017. Estudio EPINE n 28: 1990-2017. Available from http://hwsvhebronnet/epine/Global/EPINE-EPPS\%202017\%20Informe\%20 Global\%20de\%20Espa\%C3\%B1a\%20Resumenpdf.

6. Kołpa M, Wałaszek M, Różańska A, et al. Hospital-wide surveillance of healthcare-associated infections as a source of information about specific hospital needs. A 5-year observation in a multiprofile provincial hospital in the South of Poland. Int J Environ Res Public Health 2018; 15: 1956.

7. Różańska A, Wójkowska-Mach J, Bulanada M, et al. Problemy identyfikacji oraz koszty zakażeń szpitalnych. Zdrowie Publiczne i Zarządzanie Zeszyty Naukowe Ochrony Zdrowia. 2008; 6: 5-17.

8. Stambough JB, Nam D, Warren DK, et al. Decreased hospital costs and surgical site infection incidence with a universal decolonization protocol in primary total joint arthroplasty. J Arthroplasty 2017; 32: 728-734.

9. Babiak I, Pędzisz P, Janowicz J, et al. Economic analysis of 4221 revisions due to periprosthetic joint infection in Poland. Ortop Traumatol Rehabil 2017; 19: 33-44.

10. Aghdassi SJS, Schröder C, Gastmeier P. Gender-related risk factors for surgical site infections. Results from 10 years of surveillance in Germany. Antimicrob Resist Infect Control 2019; 8: 95.

11. Henkelmann R, Frosch KH, Mende M, et al. Risk factors for deep surgical site infection in patients with operatively treated tibial plateau fractures: a retrospective multicenter study. J Orthop Trauma 2021; 35: 371-377.

12. Hijas-Gómez Al, Lucas WC, Checa-García A, et al. Surgical site infection incidence and risk factors in knee arthroplasty: a 9-year prospective cohort study at a university teaching hospital in Spain. Am J Infect Control 2018; 46: 1335-1340. 
13. Le J, Dong Z, Liang J, et al. Surgical site infection following traumatic orthopaedic surgeries in geriatric patients: Incidence and prognostic risk factors. Int Wound J 2020; 17: 206-213.

14. Liu X, Dong Z, Li J, et al. Factors affecting the incidence of surgical site infection after geriatric hip fracture surgery: a retrospective multicenter study. J Orthop Surg Res 2019; 14: 382.

15. Morris BJ, Unger RZ, Archer KR, et al. Risk factors of infection after ORIF of bicondylar tibial plateau fractures. J Orthop Trauma 2013; 27: 196-200.

16. Rascoe AS, Kavanagh MD, Audet MA, et al. Factors associating with surgical site infection following operative management of malleolar fractures at an urban level 1 trauma center OTA Int 2020; 3: e077.

17. Ren $M$, Liang $W, W u Z$, et al. Risk factors of surgical site infection in geriatric orthopedic surgery: a retrospective multicenter cohort study. Geriatr Gerontol Int 2019; 19: 213-217.

18. Decyzja wykonawcza Komisji Unii Europejskiej 2018/945 z dnia 22 czerwca 2018 r. w sprawie chorób zakaźnych i powiązanych szczególnych problemów zdrowotnych, które mają być objęte nadzorem epidemiologicznym, a także odpowiednich definicji przypadków. Dz. Urz. UE L Nr 170/1 z 6/2018.

19. European Centre for Disease Prevention and Control. Surveillance of surgical site infections and prevention indicators in European hospitals - HAI-Net SSI protocol, version 2.2. Stockholm: ECDC 2017.

20. WHO Guidelines on Hand Hygiene in Health Care: a Summary. World Health Organization, Geneva 2009.

21. Global guidelines for the prevention of surgical site infection, second edition. World Health Organization, Geneva 2018.

22. Surgical site infections: prevention and treatment. NICE guideline. Published: 11 April 2019. www.nice.org.uk/guidance/ng125.

23. Berríos-Torres SI, Umscheid CA, Bratzler DW, et al. Healthcare Infection Control Practices Advisory Committee. Centers for Disease Control and Prevention Guideline for the Prevention of Surgical Site Infection, 2017. JAMA Surg 2017; 152: 784-791.

24. Ban KA, Minei JP, Laronga C, et al. American College of Surgeons and Surgical Infection Society: Surgical Site Infection Guidelines, 2016 Update. J Am Coll Surg 2017; 224: 59-74.

25. Preventing surgical site infections. Key recommendations for practice. Dublin: Joint Royal College of Surgeons in Ireland/ Royal Colleges of Physicians of Ireland Working Group on Prevention of Surgical Site Infection; 2012.

26. Targeted literature review: What are the key infection prevention and control recommendations to inform a surgical site infection (SSI) prevention quality improvement tool? Edinburgh: Health Protection Scotland; version 4.0, December 2018.

27. How-to Guide: Prevent Surgical Site Infection for Hip and Knee Arthroplasty. Institute for Healthcare Improvement, Cambridge, MA 2012. Available at www.ihi.org

28. The APSIC Guidelines for the prevention of surgical site infections. Singapore: February 2019.

29. Mangram AJ, Horan TC, Pearson ML, et al. Guideline for Prevention of Surgical Site Infection, 1999. Am J Infect Control 1999; 27: 97-134.

30. Anderson DJ, Podgorny K, Berríos-Torres SI, et al. Strategies to prevent surgical site infections in acute care hospitals: 2014 update. Infect Control Hosp Epidemiol 2014; 35: 605-627.

31. Document ICM Philly. International Consensus Meeting on Prosthetic Joint Infection. ICM Philly (online) 2018; https:// icmphilly.com/document/ (retrieved: September 10, 2021).
32. Sehulster LM, Chinn RYW, Arduino MJ, et al. Guidelines for environmental infection control in health-care facilities. Recommendations from CDC and the Healthcare Infection Control Practices Advisory Committee (HICPAC). Chicago IL; American Society for Healthcare Engineering/American Hospital Association; 2004.

33. Chapter 16: Guidelines for the Provision of Anaesthesia Services for Trauma and Orthopaedic Surgery 2021. Royal College of Anaesthesiologists.

34. Hryniewicz W, Kulig J, Ozorowski T, et al. Stosowanie antybiotyków w profilaktyce okołooperacyjnej. Narodowy Program Ochrony Antybiotyków. Warszawa 2011.

35. Hryniewicz W, Małdyk P, Ozorowski T, et al. Profilaktyka, diagnostyka i terapia zakażeń w ortopedii. Narodowy Program Ochrony Antybiotyków. Warszawa 2013.

36. Good Practice Recommendations for Surgical and Procedural Antibiotic Prophylaxis in Adults in NHS Scotland. SAPG. For review October 2021.

37. Bratzler DW, Dellinger EP, Olsen KM, et al. American Society of Health-System Pharmacists (ASHP); Infectious Diseases Society of America (IDSA); Surgical Infection Society (SIS); Society for Healthcare Epidemiology of America (SHEA). Clinical practice guidelines for antimicrobial prophylaxis in surgery. Surg Infect (Larchmt) 2013; 14: 73-156.

38. Surgical Antimicrobial Prophylaxis Clinical Guideline v2.0. Government of South Australia; November 2017.

39. European Centre for Disease Prevention and Control. Systematic review and evidence-based guidance on perioperative antibiotic prophylaxis. ECDC, Stockholm 2013.

40. American Academy of Orthopaedic Surgeons Systematic Literature Review on the Management of Surgical Site Infections. https://www.aaos.org/globalassets/quality-andpractice resources/surgical-site-infections/ssi-sr_8-29-19.pdf (published: June 9, 2018).

41. System kontroli zakażeń związanych z opieką zdrowotną w Polsce. Stowarzyszenie Epidemiologii Szpitalnej, Polskie Towarzystwo Zakażeń Szpitalnych, Polskie Stowarzyszenie Pielęgniarek Epidemiologicznych, Małopolskie Stowarzyszenie Komitetów i Zespołów ds. Zakażeń Szpitalnych, 2016. http:// www.ses.edu.pl/files/download/system_kontroli_zakazen_ szpitalnych w polsce 0.pdf. (retrieved: December 6, 2021).

42. Council recomendation of 9 June 2009 on patient safety, including the prevention and control of healthcare associated infections (2009/C 151/01).

43. Ustawa z dnia 5 grudnia 2008 r. o zapobieganiu oraz zwalczaniu zakażeń i chorób zakaźnych u ludzi. Dz. U. 2008 Nr 234 poz. 1570.

44. Ider BE, Adams J, Morton A, et al. Infection control systems In transition: the challenges for post-soviet bloc countries. J Hosp Infect 2012; 80: 277-287. 